\title{
HIGH-TEMPERATURE OXIDATION OF SILICIDE-ALUMINIDE LAYER ON THE TiAl6V4 ALLOY PREPARED BY LIQUID-PHASE SILICONIZING
}

\author{
VISOKOTEMPERATURNA OKSIDACIJA PLASTI \\ SILICID-ALUMINID, PRIPRAVLJENE S SILIKONIZIRANJEM \\ $S$ TEKOČO FAZO ZLITINE TiAl6V4
}

\author{
Tomáš František Kubatík \\ Institute of Plasma Physics AS CR, v.v.i., Za Slovankou 1782/3, 18200 Prague 8, Czech Republic \\ kubatik@ipp.cas.cz \\ Prejem rokopisa - received: 2015-01-02; sprejem za objavo - accepted for publication: 2015-03-26
}

doi: $10.17222 /$ mit.2015.002

\begin{abstract}
The method of coating with silicon from the liquid phase (also called the hot-dip method) was presented by several authors who indicated that this was an effective and inexpensive technique capable of producing Ti-Al-Si layers on titanium and titanium-alloy substrates that are rich in ternary phases. The present study examines the effects of the preparation conditions on the structure and properties of the layers. These layers provide excellent protection from high-temperature oxidation, even at a temperature of $950{ }^{\circ} \mathrm{C}$. It was proved with SEM and X-ray analyses that the original $\tau_{2}$ ternary phase almost completely decomposed into pure $\mathrm{Ti}_{5} \mathrm{Si}_{4}$ and TiSi silicides at the temperature of $950{ }^{\circ} \mathrm{C}$. The formed layer, consisting of silicide sub-layers, exhibited superior protective properties in high-temperature applications.
\end{abstract}

Keywords: TiAl6V4, silicides, high-temperature oxidation, liquid-phase siliconizing

Metodo prekrivanja s silicijem iz tekoče faze (včasih imenovano hot-dip metoda) je predstavilo več avtorjev, ki so potrdili, da je to učinkovita in poceni tehnika, s katero je mogoče izdelati Ti-Al-Si plasti na podlagi iz titana in titanovih zlitin, ki vsebujejo ternarne faze. Predstavljena študija preiskuje vpliv pogojev priprave na strukturo in lastnosti plasti. Te plasti zagotavljajo odlično zaščito pred visokotemperaturno oksidacijo, celo pri temperaturi $950^{\circ} \mathrm{C}$. S SEM in $\mathrm{Z}$ rentgensko analizo je bilo dokazano, da se prvotna ternarna faza $\tau_{2}$, pri temperaturi $950{ }^{\circ} \mathrm{C}$, skoraj v celoti razgradi v čisti $\mathrm{Ti}_{5} \mathrm{Si}_{4}$ in $\mathrm{TiSi}$ silicid. $\mathrm{Nastala}$ plast, ki jo sestavlja več podplasti je pokazala odlične zaščitne lastnosti pri visokotemperaturni uporabi.

Ključne besede: TiAl6V4, silicidi, visokotemperaturna oksidacija, silikoniziranje v tekoči fazi

\section{INTRODUCTION}

Protective layers based on silicide-aluminide phases prepared from the liquid phase were studied by various authors ${ }^{1-4}$ and were shown to exhibit the potential of acting as protective layers where titanium and its alloys are used in high-temperature applications..$^{5-13}$ The principle of the method is based on the high affinity of silicon and aluminium to titanium. During the immersion of titanium and its alloys in the aluminum melt comprising silicon, a reaction forming a Ti-Al-Si phase at the interface takes place. The temperature of the melt and the silicon content in the melt have effects on the kinetics of the growth of the interface layers as well as on their phase composition. These layers provide an excellent barrier to the diffusion of both oxygen and nitrogen at high temperatures. In high-temperature applications, the layers composed of silicide-aluminide phases cannot be compared with silicides but may offer superior mechanical properties at both high and low temperatures.

The major phase present in these layers, the $\tau_{2}$ phase, was first described by Brukl et al. ${ }^{14}$ as $\operatorname{Ti}\left(\mathrm{Al}_{\mathrm{x}} \mathrm{Si}_{1-\mathrm{x}}\right)_{2}$ where $x$ is in the range from 0.15 to 0.3 , and further characterized by Schubert et al. ${ }^{15}$ with the orthorhombic structure and a space group $(\mathrm{Cmcm})$. Layers rich in this phase exhibit an excellent oxidation resistance. During the course of oxidation, a compact film rich in $\mathrm{SiO}_{2}$ is formed on the surface of a layer, which substantially mitigates oxygen diffusion. This work is focused on the study of the changes in the phase composition during a high-temperature oxidation of the layers formed by the $\tau_{2}$ phase.

\section{EXPERIMENTAL WORK}

The substrate material used in the presented work was the most common titanium alloy, TiAl6V4. Specimens were manufactured as cylinders of $10 \mathrm{~mm}$ in diameter and $6 \mathrm{~mm}$ in height. They were ground using P180-1200 SiC emery papers. Then they were polished with diamond pastes up to $1 \mu \mathrm{m}$. This was followed by degreasing in acetone in an ultrasonic apparatus, rinsing with distilled water, and drying with compressed air. An alloy melt of AlSi20 \% of mass fractions was prepared by melting aluminum (99.5\% purity) with silicon ( $99.99 \%$ purity). To ensure the required homogeneity, the melt was agitated for $30 \mathrm{~min}$ and then kept at $650{ }^{\circ} \mathrm{C}$. Then the oxide surface layer was raked off and the TiAl6V4-alloy specimens were immediately introduced. 
The melt was agitated again and the specimens were held in the melt for $60 \mathrm{~min}$. At the end of the process, the samples were removed from the bath and air-cooled. The microstructure of the cross-sections of the samples was observed by a scanning electron microscope, EVO MA 15 (Carl Zeiss SMT, Germany, SEM).

The specimens used in the oxidation experiments were treated in $15 \% \mathrm{HCl}$ to remove the residues of solidified melt. The specimens were subjected to cyclic oxidation in an electric-resistance furnace at the temperatures of $850{ }^{\circ} \mathrm{C}$ and $950{ }^{\circ} \mathrm{C}$ for $144 \mathrm{~h}$ in air. The results were expressed as weight gains due to oxidation versus oxidation duration. After the oxidation the specimens were mounted in metacrylate resin, ground polished and studied with SEM. A phase analysis was performed with a D8 Discover diffractometer (Bruker, Germany); diffracted $\mathrm{Cu}-K \alpha$ radiation was detected with a 1D LynxEye detector.

\section{RESULTS AND DISCUSSION}

\subsection{Microstructure}

The temperature applied in the coating process has a significant effect on both the growth rate of the layers and on the layer quality. From previous experiments ${ }^{13}$, the temperature of $650{ }^{\circ} \mathrm{C}$ was chosen as the highest temperature for this process. Up to this temperature, the layer is formed only by Ti-Al-Si ternary phases.

The microstructure of the layers prepared by immersion in the AlSi20 melt (with solid silicon) at the temperature of $650{ }^{\circ} \mathrm{C}$ for $1 \mathrm{~h}$ (Figure 1) is compact, non-porous and free from any cracks and fissures. The thickness of the layer reaches approximately $55 \mu \mathrm{m}$. The chemical composition across the layer is constant $11.2 \% \mathrm{Al}$ (in amount fractions, $x / \%$ ), $55.6 \% \mathrm{Si}, 31.9 \%$ $\mathrm{Ti}$, and $1.3 \% \mathrm{~V}$. This chemical composition corresponds

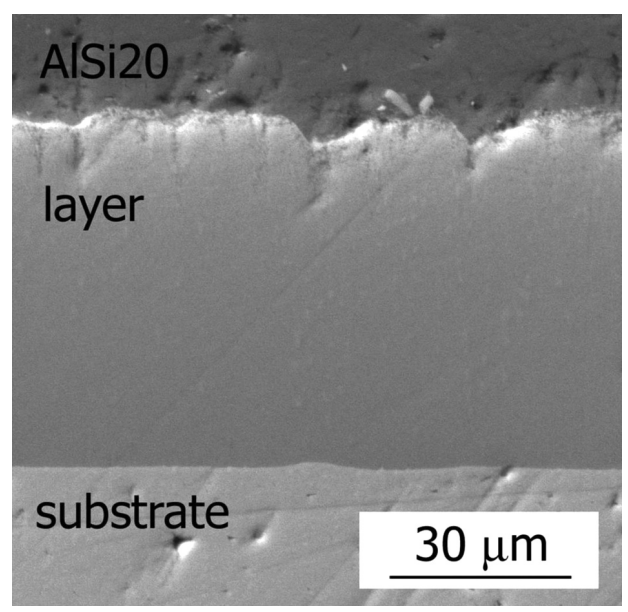

Figure 1: Microstructure of the cross-section of a layer prepared in the AlSi20 melt, at the temperature of $650{ }^{\circ} \mathrm{C}$ for $1 \mathrm{~h}$

Slika 1: Mikrostruktura preseka plasti, pripravljene v talini AlSi20, $1 \mathrm{~h}$ pri temperaturi $650^{\circ} \mathrm{C}$

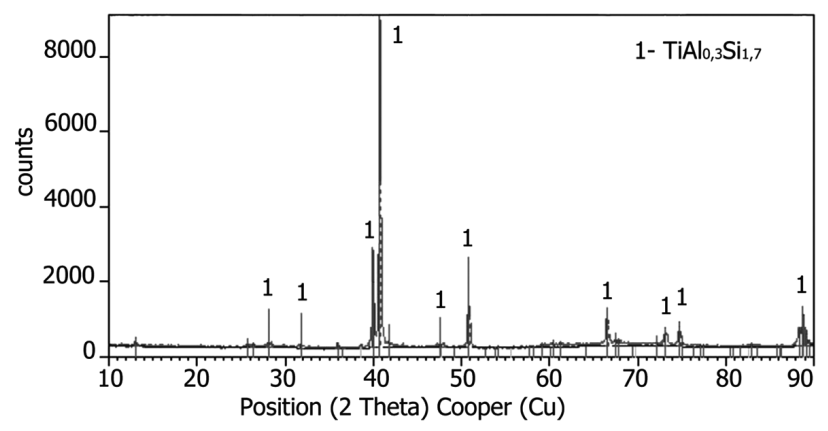

Figure 2: XRD pattern of a cross-section of the layer prepared in the AlSi20 melt

Slika 2: Rentgenogram prečnega preseka plasti, pripravljene $\mathrm{v}$ talini A1Si20

to the $\tau_{2}$ phase that occurs as the main product of the liquid-phase siliconizing process.

According to the phase analysis, the major phase present is $\mathrm{TiAl}_{0.3} \mathrm{Si}_{1.7}$ also known as the $\tau_{2}$ phase, shown in Figure 2. This phase was already identified by the authors who studied the preparation of layers from silicon-rich melts.

\subsection{Oxidation resistance}

The oxidation resistance of the prepared layer was evaluated with cyclic-oxidation tests. The results of the oxidation at $850{ }^{\circ} \mathrm{C}$ are presented in Figure 3. The plot represents the weight gains as a function of the oxidation duration. The weight of the scales delaminated from the samples was added to the reported weight. The uncoated samples of titanium and TiAl6V4 alloy were used as the references. The weight gain of the TiAl6V4 alloy $\left(0.0986 \mathrm{~g} / \mathrm{cm}^{2}\right.$ after $\left.144 \mathrm{~h}\right)$ is almost 64 times higher than that of the specimen coated with a protective Ti-Al-Si layer. It is clearly seen that the surface layer provides a considerable protection to the alloy when exposed to the

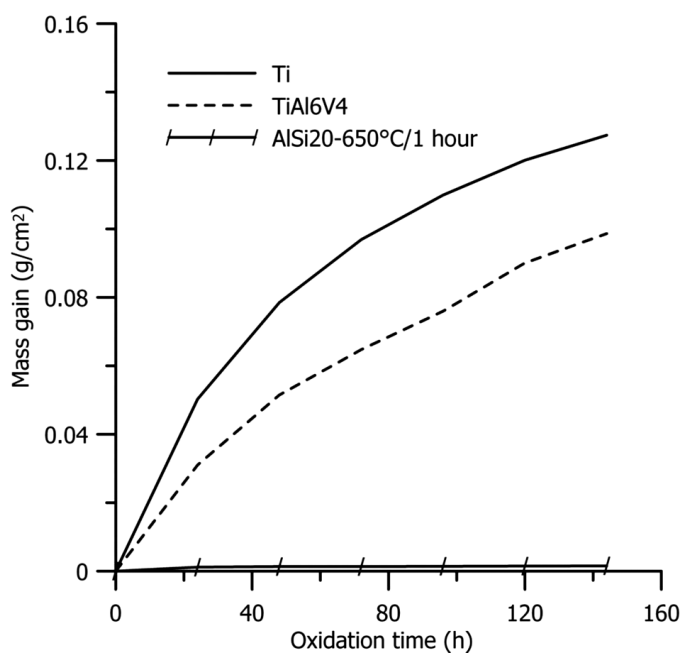

Figure 3: Cyclic-oxidation curves of coated TiAl6V4, uncoated TiAl6V4 and Ti at $850{ }^{\circ} \mathrm{C}$

Slika 3: Krivulje ciklične oksidacije TiAl6V4 s prekritjem, TiAl6V4 brez prekritja in Ti, pri $850{ }^{\circ} \mathrm{C}$ 


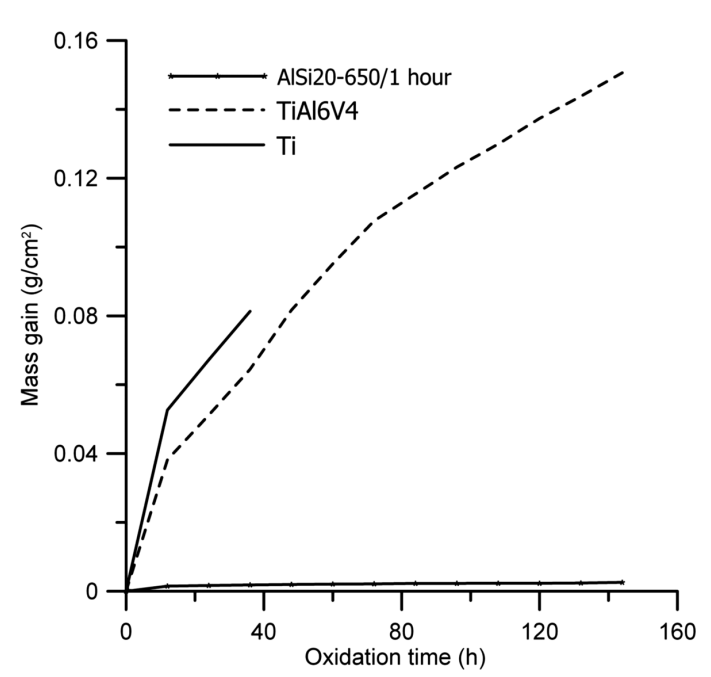

Figure 4: Cyclic-oxidation curves of coated TiAl6V4, uncoated TiAl6V4 and $\mathrm{Ti}$ at $950{ }^{\circ} \mathrm{C}$

Slika 4: Krivulje ciklične oksidacije TiAl6V4 s prekritjem, TiAl6V4 brez prekritja in Ti, pri $950{ }^{\circ} \mathrm{C}$

air at high temperatures. The character of the kinetic curve shown in Figure 3 indicates that the greatest weight gain is reached during the first $24 \mathrm{~h}$. After that, the weight of the tested sample remains almost constant. When taking into account that the testing temperature is much higher than the applicability limits of titanium alloys and the protection Ti-Al-Si layers, it can be stated that the proposed surface treatment provides an excellent protection.

The results of the cyclic oxidation at the temperature of $950{ }^{\circ} \mathrm{C}$ are summarized in Figure 4. Uncoated titanium exhibited an enormously high oxidation rate at the areas where the oxide scales were peeling off from the surface. In the case of the TiAl6V4-alloy specimens, the weight gains were also high. The oxidation kinetic curve does not exhibit a purely parabolic character, mainly due to a massive delamination of the surface oxide scales. The weight gain after $144 \mathrm{~h}$ of oxidation was almost 58 times higher in the case of the TiAl6V4 alloy $(0.150$ $\mathrm{g} / \mathrm{cm}^{2}$ ) than in the case of the specimen coated with a protective layer $\left(0.00257 \mathrm{~g} / \mathrm{cm}^{2}\right)$. The high oxidation resistance of the layers is attributed to the formation of compact silicide sub-layers, as will be discussed bellow.

\subsection{Microstructure and phase analysis of the layers after the oxidation}

After performing the oxidation experiments, the changes in the microstructure of the layers were examined with a scanning electron microscope. The microstructure of the cross-section of an as-oxidized layer after the exposure at $850{ }^{\circ} \mathrm{C}$ for $144 \mathrm{~h}$ is shown in Figure 5. It can be seen from the microstructure that the layer structure was subjected to considerable changes. The initially formed layer decomposed into several sub-layers. Chemical microanalysis results and results of the X-ray phase analysis indicate that two new sub-layers were

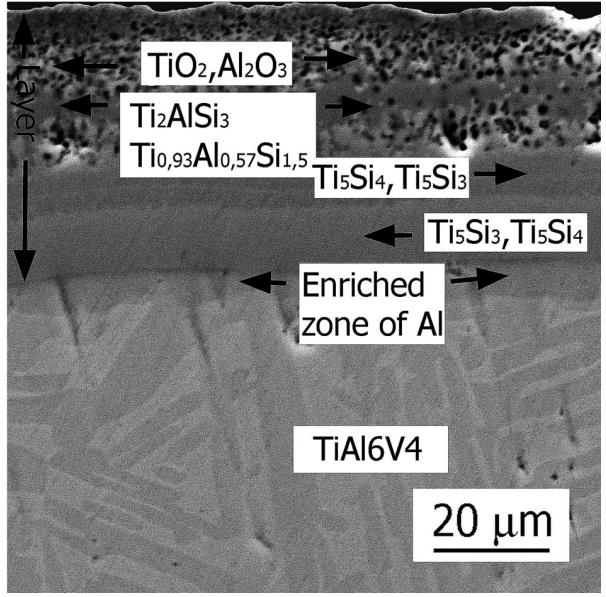

Figure 5: SEM macrograph of the cross-section of the layer prepared in the AlSi20 melt, after the oxidation at $850{ }^{\circ} \mathrm{C}$ for $144 \mathrm{~h}$

Slika 5: SEM-posnetek preseka plasti, pripravljene v talini AlSi20, po oksidaciji $144 \mathrm{~h}$ na temperaturi $850{ }^{\circ} \mathrm{C}$

formed, constituted by $\mathrm{Ti}_{5} \mathrm{Si}_{4}$ silicide, probably also containing the TiSi phase, detected with the phase analysis. These layers are followed by an inhomogeneous and porous layer, composed of ternary Ti-Al-Si phases. The SEM-EDS results revealed that the $\tau_{2}$ phase is present, together with the other ternary phases, more enriched in aluminum. It is suggested that, in analogy to the structure of the layer oxidized at $950{ }^{\circ} \mathrm{C}$, the initially present silicide-aluminide layer decomposes yielding thermodynamically stable silicides, whose subsequent growth acts as the driving force of aluminium diffusion into the substrate and toward the layer surface. This assumption is also supported by the presence of the original Ti-Al-Si phase with a higher aluminum content. This topmost sub-layer hinders the diffusion of aluminum.

The progressive weight gain experienced during the oxidation process indicate that in the early stages the weight gain is minimal, probably owing to the aluminum

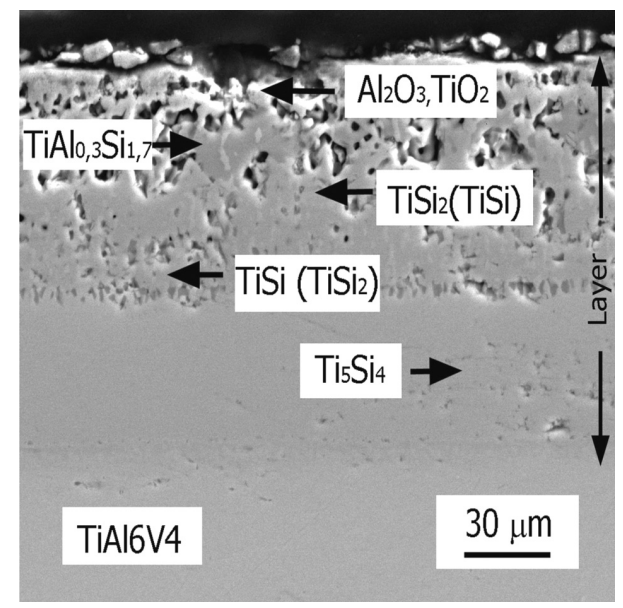

Figure 6: SEM micrograph of the cross-section of the layer prepared in the AlSi20 melt, after the oxidation at $950{ }^{\circ} \mathrm{C}$ for $144 \mathrm{~h}$

Slika 6: SEM-posnetek preseka plasti, pripravljene v talini A1Si20, po oksidaciji $144 \mathrm{~h}$ na temperaturi $950{ }^{\circ} \mathrm{C}$ 
diffusion toward the surface and its subsequent oxidation. After that, the oxidation rate is close to the experimental error of the measurement. This may be related to the fact that aluminum cannot diffuse easily within a spongy surface structure. The cross-section of the layer oxidized at $950{ }^{\circ} \mathrm{C}$ for $144 \mathrm{~h}$ is displayed in Figure 6. In this case, there were substantial changes to the layer structure as well. A new layer was formed, composed of several sub-layers. With the chemical microanalysis and X-ray analysis, it can be clearly demonstrated that the original $\tau_{2}$ phase decomposed yielding silicide sublayers.

The layer located close to the substrate is constituted by the $\mathrm{Ti}_{5} \mathrm{Si}_{3}$ silicide, which is more enriched in titanium. This layer is compact and homogeneous, with a thickness of approximately $45 \mu \mathrm{m}$. The next layer is a thin intermediate layer composed of nearly pure aluminum (with TiAl determined with the phase analysis). The layer after this one is an inhomogeneous and rather porous layer of TiSi silicide with a thickness of approximately $40 \mu \mathrm{m}$. This layer probably also contains particles of $\mathrm{TiSi}_{2}$ silicide that can be observed in the microphotograph, but failed to be precisely detected with the SEM microanalysis. The presence of this silicide was confirmed with the XRD phase analysis. This silicide layer gradually turns into an inhomogeneous layer containing a great number of pores, in which $\mathrm{Al}$ and $\mathrm{Ti}$ oxides as well as residues of the original Ti-Al-Si phase were detected by means of a semi-quantitative chemical analysis. Most probably, this is related to the spongy surface of the prepared layers, as shown in Figure 1. This also makes oxygen diffusion easier and facilitates its oxidation on the layer surface. It can be assumed that at such a high temperature, the original silicide-aluminide phase tends to decompose yielding thermodynamically stable TiSi, $\mathrm{Ti}_{5} \mathrm{Si}_{4}\left(\mathrm{Ti}_{5} \mathrm{Si}_{3}\right.$ has a similar diffraction pattern), and $\mathrm{TiSi}_{2}$ silicides, which were detected as the major constituents with the X-ray phase analysis.

The growth of the silicides causes aluminum to diffuse along the layer/substrate interface and, primarily, to diffuse toward the surface where it is subsequently oxidized. This assumption is also supported by the pre-

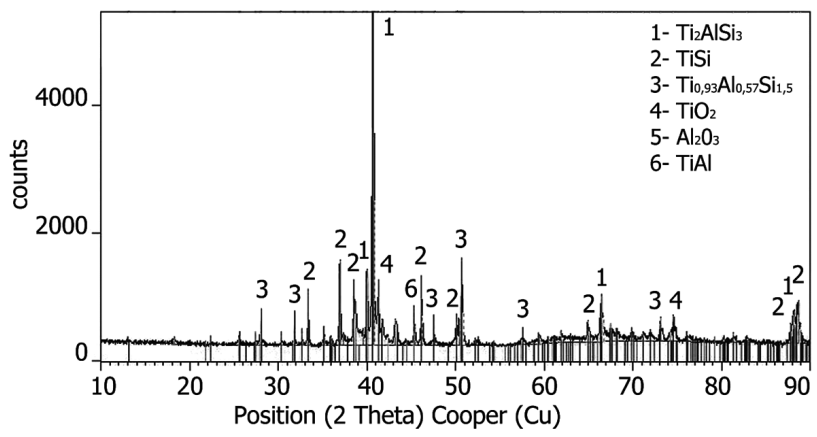

Figure 7: XRD pattern of the cross-section of the layer prepared in the AlSi20 melt, oxidized at $850{ }^{\circ} \mathrm{C}$ for $144 \mathrm{~h}$

Slika 7: Rentgenogram prečnega preseka plasti, pripravljene v talini AlSi20, po oksidaciji 144 h na temperaturi $850{ }^{\circ} \mathrm{C}$ sence of a thin aluminum layer between the two silicide sub-layers, detected in the layer structure after the oxidation at both temperatures $\left(850{ }^{\circ} \mathrm{C}\right.$ and $\left.950{ }^{\circ} \mathrm{C}\right)$. It can be assumed that the considerable resistance to high-temperature oxidation can be attributed mainly to the presence of the sub-layer constituted by the $\mathrm{Ti}_{5} \mathrm{Si}_{4}$ silicide. Different chemical compositions of the two sub-layers can be observed, which remain constant across the entire width of the newly formed sub-layers. Vanadium is uniformly distributed across the entire thickness of the layer.

The layers obtained with the oxidation at $850{ }^{\circ} \mathrm{C}$ and at $950{ }^{\circ} \mathrm{C}$ were subjected to a phase analysis. After the oxidation at the temperature of $850{ }^{\circ} \mathrm{C}$ (Figure 7), two major phases were detected. They were ternary silicidealuminide phases having significantly higher aluminum contents than the original $\tau_{2}$ phase. The minor phases included TiSi and TiAl. It was reported ${ }^{2}$ that the intermetallic phases of TiAl and TiSi were formed due to the reaction of the substrate (Ti-Al alloy) with the ternary phase of Ti-Al-Si in accordance with the following Equation (1):

$$
\mathrm{Ti}-\mathrm{Al}+(\mathrm{Ti}-\mathrm{Al}-\mathrm{Si}) \rightarrow \mathrm{TiAl}+\mathrm{TiSi}
$$

The achieved results suggest that nuclei of the TiSi phase were formed and continued to grow within the original layer. Due to this process, aluminum was pushed out and allowed to diffuse, producing aluminum-enriched Ti-Al-Si phases.

This assumption was confirmed by the presence of aluminum in the substrate near the layer/substrate interface, by the large quantities of aluminum found on the layer surface and by the presence of the thin intermediate layer at the interface between the silicide sub-layers. At the temperature of $950{ }^{\circ} \mathrm{C}$ these changes proceeded more rapidly and caused a nearly complete decomposition of the original layer formed by the $\tau_{2}$ phase. The phases detected with the $\mathrm{X}$-ray analysis at this high temperature included $\mathrm{TiSi}, \mathrm{TiSi}_{2}, \mathrm{TiO}_{2}$ and the silicide-aluminide $\tau_{2}$ phase as the dominant phase (Figure 8).

The minor phases detected were $\mathrm{Ti}_{5} \mathrm{Si}_{4}$ and $\mathrm{Al}_{2} \mathrm{O}_{3}$. These analyses corresponded well with the microanalyses performed with SEM-EDS. Due to the forma-

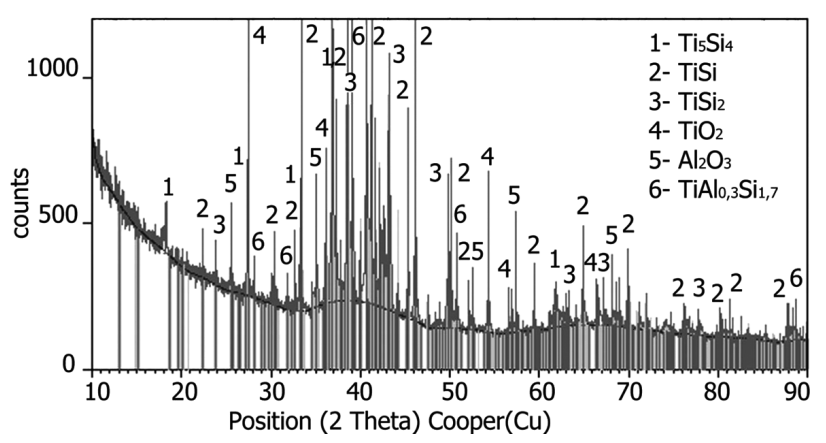

Figure 8: XRD pattern of the cross-section of the layer prepared in the AlSi20 melt, oxidized at $950{ }^{\circ} \mathrm{C}$ for $144 \mathrm{~h}$

Slika 8: Rentgenogram prečnega preseka plasti, pripravljene $\mathrm{v}$ talini AlSi20, po oksidaciji 144 h na temperaturi $950{ }^{\circ} \mathrm{C}$ 
tion of the thermodynamically stable $\mathrm{TiSi}$ and $\mathrm{Ti}_{5} \mathrm{Si}_{4}$ $\left(\mathrm{Ti}_{5} \mathrm{Si}_{3}\right.$ has a similar diffraction pattern) silicides, the oxidation rates were considerably lower, as can be concluded from the data in Figure 5.

\section{CONCLUSIONS}

The liquid-phase silicon-aluminium coating process can be adopted to produce compact and homogeneous surface layers constituted by the ternary phase $\mathrm{TiAl}_{0.3} \mathrm{Si}_{1.7}$. Such layers are prepared from the AlSi20 melt, at a temperature of $650{ }^{\circ} \mathrm{C}$ with the resulting thickness of $55 \mu \mathrm{m}$. The layers prepared in the present study provide outstanding protection from cyclic high-temperature oxidation, at both $850{ }^{\circ} \mathrm{C}$ and $950{ }^{\circ} \mathrm{C}$ in air. In the early stages of the oxidation, there is a gradual increase in the weight gain, but after about $30 \mathrm{~h}$ of exposure the weight gains are almost too low to be detected on the specimens used. The analyses of the as-oxidized layers indicate that the original layer decomposes, yielding compact and homogeneous sub-layers constituted solely by the $\mathrm{Ti}_{5} \mathrm{Si}_{3}$ and $\mathrm{TiSi}$ silicides. Due to the formation of these silicide sub-layers, a considerable oxidation resistance is reached, allowing the use of titanium alloys in high-temperature applications. The present study demonstrates that highly resistant protective layers suitable for high-temperature applications can be prepared using a simple and cost-effective technique.

\section{Acknowledgement}

The research of the surface-protective layers on TiAl6V4 is financially supported by research project VZ MSM 2579478701.

\section{REFERENCES}

${ }^{1}$ P. Novák, I. Marek, L. Mejzlíková, A. Michalcová, D. Vojtěch, Reactive-Sintering Production of Intermetallics, Mater. Tehnol., 46 (2012) 6, 559-562
${ }^{2}$ H. P. Xiong, W. Mao, Y. H. Xie, W. L. Ma, Y. F. Chen, X. H. Li, J. P. Li, Y. Y. Cheng, Liquid-phase siliconizing by Al-Si alloys at the surface of a TiAl-based alloy and improvement in oxidation resistance, Acta Materialia, 52 (2004) 9, 2605-2620, doi:10.1016/j.actamat. 2004.02.008

${ }^{3}$ M. J. Freiría Gándara, Aluminium: The Metal of Choice, Mater. Tehnol., 47 (2013) 3, 261-265

${ }^{4}$ T. Kubatík, M. Jáglová, E. Kalabisová, V. Č́íhal, Improvement of oxidation resistance of TiAl6V4 alloy by siliconizing from liquid phase using melts with high silicon content, Journal of Alloys and Compounds, 509 (2011) 18, 5493-5499, doi:10.1016/j.jallcom.2011. 02.068

${ }^{5}$ D. B. Lee, S. W. Woo, High temperature oxidation of Ti-47\%Al$1.7 \% \mathrm{~W}-3.7 \% \mathrm{Zr}$ alloys, Intermetallics, 13 (2005) 2, 169-177, doi:10.1016/j.intermet.2004.07.043

${ }^{6}$ D. Vojtěch, J. Čížkovský, P. Novák, J. Šerák, T. Fabián, Effect of niobium on the structure and high-temperature oxidation of TiAl- $\mathrm{Ti}_{5} \mathrm{Si}_{3}$ eutectic alloy, Intermetallics, 16 (2008) 7, 896-903, doi:10.1016/j.intermet.2008.04.005

${ }^{7}$ Y. H. Celik, Investigating the Effect of Cutting Parameters on the Hole Quality in Drilling the TiAl6V4 Alloy, Mater. Tehnol., 48 (2014) 5, 653-659

${ }^{8}$ W. Liang, X. G. Zhao, Improving the oxidation resistance of TiAl-based alloy by siliconizing, Scripta Materialia, 44 (2001) 7, 1049-1054, doi:10.1016/S1359-6462(01)00675-3

${ }^{9}$ J. D. Majumdar, A. Weisheit, B. L. Mordike, I. Manna, Laser surface alloying of $\mathrm{Ti}$ with $\mathrm{Si}, \mathrm{Al}$ and $\mathrm{Si}+\mathrm{Al}$ for an improved oxidation resistance, Materials Science and Engineering A, 266 (1999) 1-2, 123-134, doi:10.1016/S0921-5093(99)00045-3

${ }^{10}$ M. Bassem, H. D. Kessler, D. J. McPherson, The Titanium-Silicon System, Transactions of American Society for Metals, 44 (1952), 518-538

${ }^{11}$ E. A. Loria, Gamma titanium aluminides as prospective structural materials, Intermetallics, 8 (2000) 9-11, 1339-1345, doi:10.1016/ S0966-9795(00)00073-X

${ }^{12}$ K. Funatani, Emerging technology in surface modification of light metals, Surface and Coatings Technology, 133-134 (2000), 264-272, doi:10.1016/S0257-8972(00)00940-3

${ }^{13}$ T. Kubatík, E. Kalabisová, Vrstvy Ti-Al-Si na titanu a slitině TiAl6V4, SVUOM, Praha 2010

${ }^{14}$ C. Brukl, H. Nowotny, O. Schob, F. Benesovsky, The crystal structure of TiSi, Ti(Al,Si)2 and Mo(Al,Si)2, Monatsh Chem, 92 (1961), 781-788

${ }^{15}$ K. Schubert, H. G. Meissner, A. Raman, W. Rossteutscher, Einige Strukturdaten metallischer Phasen, Naturwissenschaften, 51 (1964) 12, 287, doi:10.1007/BF00625465 